\title{
Trajectories of brain development: point of vulnerability or window of opportunity?
}

\author{
Susan L. Andersen* \\ Laboratory of Development Psychopharmocology, Department of Psychiatry, McLean Hospital and Harvard Medical School, \\ 115 Mill Street, Belmont, MA 02478, USA
}

Accepted 29 January 2003

\begin{abstract}
Brain development is a remarkable process. Progenitor cells are born, differentiate, and migrate to their final locations. Axons and dendrites branch and form important synaptic connections that set the stage for encoding information potentially for the rest of life. In the mammalian brain, synapses and receptors within most regions are overproduced and eliminated by as much as $50 \%$ during two phases of life: immediately before birth and during the transitions from childhood, adolescence, to adulthood. This process results in different critical and sensitive periods of brain development. Since Hebb (1949) first postulated that the strengthening of synaptic elements occurs through functional validation, researchers have applied this approach to understanding the sculpting of the immature brain. In this manner, the brain becomes wired to match the needs of the environment. Extensions of this hypothesis posit that exposure to both positive and negative elements before adolescence can imprint on the final adult topography in a manner that differs from exposure to the same elements after adolescence. This review endeavors to provide an overview of key components of mammalian brain development while simultaneously providing a framework for how perturbations during these changes uniquely impinge on the final outcome.
\end{abstract}

(C) 2003 Elsevier Science Ltd. All rights reserved.

Keywords: Adolescence; Development; Insult; Sex; Vulnerability

\section{Background and theoretical framework}

Nearly $22.1 \%$ of the adult population of the United States has a diagnosable mental illness. Differences in diagnostic issues may slightly influence this statistic, but the World Health Organization estimates that mental disorders are on the rise [94]. Depression, for example, is projected to become the second leading disorder by 2020 [94]. Despite the complete mapping of the human genome, the genetic culprits that underlie the most prevalent psychiatric disorders in our society remain elusive. Concordance rates between monozygotic twins fall significantly short of $100 \%$ for most disorders, suggesting a strong role for the environment for the etiology or expression. For example, data from twin studies suggests that the heritability index for schizophrenia is $75 \%$, depression $70 \%$, hyperactivity $81 \%$, and personality disorders $42 \%$, although no single gene has been identified [154]. In an age full of great technological

\footnotetext{
* Tel.: +1-617-855-3211; fax: + 1-617-855-3479.

E-mail address: sandersen@mclean.harvard.edu (S.L. Andersen).
}

advances in genotyping with microarray analyses [156], the importance of the environment on the final phenotypic expression still cannot be minimized [64].

This review endeavors to provide a framework of brain development with an emphasis on the transitions between childhood, adolescence, and adulthood as it relates to psychopathology. Once the framework is established, the influence of intrinsic and extrinsic factors on development will be discussed. Though this window of observation, it is hoped that new insights into the unique aspects of the phenotypic expression of various disorders following environmental challenges will be provided.

\subsection{The maturation of psychopathology}

The illnesses of attention deficit hyperactivity disorder (ADHD), Tourette's syndrome (TS), schizophrenia, and depression have a very strong tie that binds them together. Symptoms in all of these disorders change markedly across lifespan periods that coincide with hormonal changes [54]. Disorders that begin in childhood, such as ADHD and TS, 
become significantly worse during puberty, but then symptoms wane in the majority of cases [129]. Schizophrenia typically appears post-pubertally, but symptoms, including dystonias, increase during the postpartum and menopausal periods [189]. Depression typically emerges post-pubertally, with an average age of onset of 20 years [17]. The prevalence of substance use disorder (SUD) also follows a similar course. For example, stimulant abuse rises sharply between the ages of 12 and 16, increasing from 2.9 to $16.4 \%$, respectively, [183]. Taken together, these data suggest that puberty is a key maturational period that sets the stage for potentially a lifetime free from or full of psychopathology.

Without debate, development should be full of successful achievements of each and every milestone. Information about brain development, complete with its points of vulnerability or windows of opportunity, provides a starting point to understanding the emergence, course, and severity of psychopathology in general. Given that mental illness is polygenic in nature, multiple approaches are needed to understand its basis. At the very least, knowledge on how genetics, sex, and risk factors interact with normal ontogeny will provide a framework to guide research on the phenotypic expression of neuropsychiatric disorders [139]. At its greatest, this knowledge may offer novel insights into how to make this transition smooth for individuals at risk for psychopathology and may lead to new therapeutic approaches for treatment.

\subsection{Sex differences in the psychopathology}

One of the most puzzling aspects of psychiatric illnesses is the occurrence of dramatic sex differences in prevalence rates and course without obvious anatomical differences between males and females (although subtle differences are observed). Early childhood disorders, such as ADHD and TS, preferentially affect males over females (ADHD: 2-9-fold more prevalent in males; [16,29]; TS: 3-4-fold more prevalent in males than females; [129]). Differences in the onset of psychotic symptoms in schizophrenia are also subject to sex differences, but in this case, it is the age of onset that is delayed by an average of 4-5 years in females, rather than gender differences in prevalence rate [86,134]. However, a second peak of onset of schizophrenia is observed between 45 and 49 years of age that coincides with menopause $[83,86]$. Even within the diagnosis of schizophrenia, gender differences in psychotropic treatment response are also apparent whereby women fare better $[78,189]$, but are also more prone to adverse, dystonic side effects, especially with the onset of menopause [37,185]. SUD also affects men more than women. At least in terms of dopamine-related disorders, being female seems to offer some advantage or protection over males in terms of risk or severity of these illnesses. Depression, in contrast, afflicts females to a much greater extent [17].
Numerous hypotheses have been proposed to explain gender differences in symptomatology and prevalence rates for these and other disorders [189]. For example, estrogen is hypothesized to have neuromodulatory and neurotrophic effects that buffer the expression of pathology [83,87]. Alternatively, differences in social pressures [188] and sex differences in stress reactivity [42], which may be part and parcel of the same process, have been proposed. To date, no one unifying theory has emerged, which is not to underscore its importance for understanding the implications for etiology or treatment.

\section{Normal brain development}

The trajectory of brain development occurs in multiple stages as reviewed below. Schematically, this timeline is found in Fig. 1. Within the timeline, different brain regions have a unique course of ontogeny. Late developing structures, including the cortex, hippocampus and the cerebellum [77,103,107], set the stage for differential periods of vulnerability in a regionally specific manner.

\subsection{Prenatal brain development}

Neuronal progenitor cells are born, differentiate, and laid down in an inside-out pattern. Larger cells, like pyramidal cells, typically arrive earlier than smaller cells (i.e. granule cells) and adhere to some degree of a phylogeny in which older regions are established first [103]. Proper innervation patterns are guided by radial glia or target-derived neurotrophic factors [174]. Once neurons reach their final destination at about the 16th fetal week, they arborize and branch in an attempt to establish appropriate connections [192]. Axon collaterals connect to numerous regions in the brain before the neuron finishes migrating to its target location [105]. Brain-derived neurotrophic factor (BDNF), nerve growth factor (NGF), glia-derived GF (GDNF), CNTF, and IGF-1 [104] influence the migration or retraction of neurons. Concentrations of ephrins guide neurons further by establishing a chemical gradient to follow [116].

Growth factors continue to play an integral role in dendritic branching once neurons reach their target. The expression of growth factors reaches its highest level during the prenatal period as neurons first establish synaptic contacts, and rises again in a regionally specific manner during postnatal development in the rat [106,213]. For example, mRNA for BDNF reaches an adult level in hippocampus by 7 days and remains elevated throughout juvenile development. In contrast, cortical levels peak at approximately 14 days of age and then gradually decline. Growth factors continue to play a role in synaptic plasticity throughout the lifespan, and are integral for neuronal changes associated with learning [80], drug exposure [58, 84], and neuronal repair following injury or transplantation [115]. Whether it is the amount of growth factors that is 


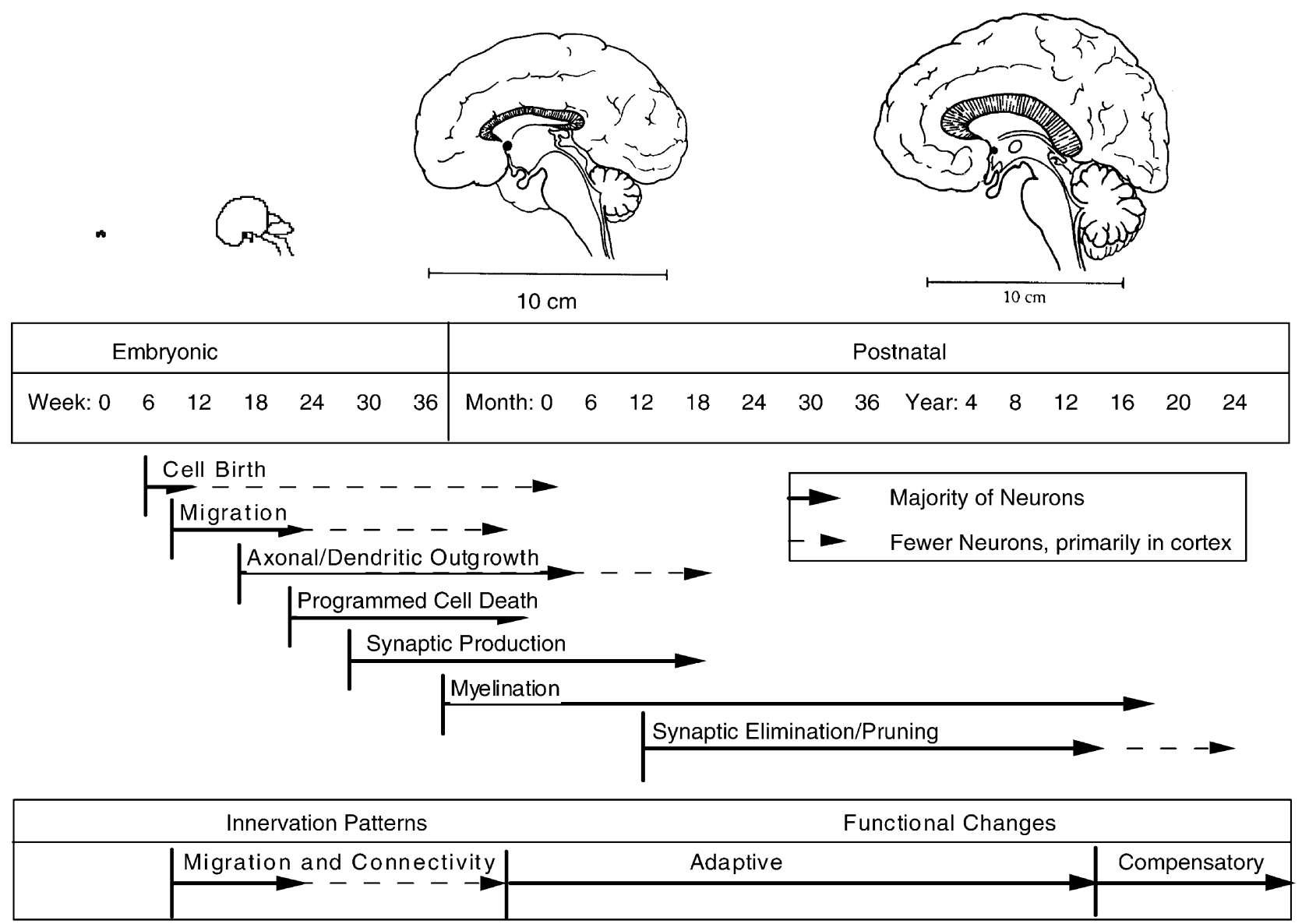

Fig. 1. The stages of brain development (top) and different windows of vulnerability (bottom). Developmental processes occur in phases, setting the stage for potential periods of vulnerability. Insults early in life (bottom) will be assimilated into innervation patterns, whereas a later pre-pubertal insult will cause functional changes that are more adaptive.

expressed or their interaction with other factors, harnessing these important mediators of brain development may offer a novel mechanism to alter trajectories following an insult.

Once the initial phase of innervation has occurred, approximately $50 \%$ of all neurons are eliminated during the period immediately before birth, in a process known as programmed cell death or apoptosis $[102,124]$. During this period, dramatic morphological rearrangements occur with the hypothesized goal to increase efficiency of synaptic transmission [40,100,172]. A second wave of overproduction and elimination occurs later in life during periadolescence.

\subsection{Postnatal brain development}

Monoamine neurons are detectable by embryonic ages 13-18 days in the rat [161]. At birth, dopaminergic markers, including tyrosine hydroxylase activity, dopamine uptake sites, and dopamine content, are approximately $10 \%$ of levels in the adult rat $[34,43]$. These markers increase monotonically and attain adult levels between 28 and 35 days in the rat. Monoamine oxidase (MAO) increases, and accordingly, turnover ratios (metabolite to transmitter) decrease with age $[110,210]$. Firing rates of nigrostriatal neurons increase gradually [167,212]. Dopamine D1 and D2 receptor density increases in a linear fashion during the first 4 weeks of life and reach their adult-like density at this stage $[159,163,176]$.

During the periadolescent period, the second wave of neuronal rearrangements occurs. This wave witnesses a tremendous overshoot of synapses and receptors during periadolescence, followed by their pruning or competitive elimination. (For a comparison of ages and stages of rat versus human developmental periods, see Fig. 2.) This fundamental developmental strategy is common to most regions of the mammalian central nervous system and has been observed in humans $[72,98,190]$, primates $[138,175$, 179], and rats [13,71,209]. Between 7 and 15 years of age in humans, synaptic density in the frontal cortex decreases by approximately $40 \%[98,174]$. Comparable changes occur in the human receptors for dopamine [190], glutamate [20], and neurotensin [147].

Huttenlocher [98] was the first to demonstrate that the timing of synaptic production and elimination of the postnatal human brain differed across different regions of the cortex. The density of synapses in the primary visual 


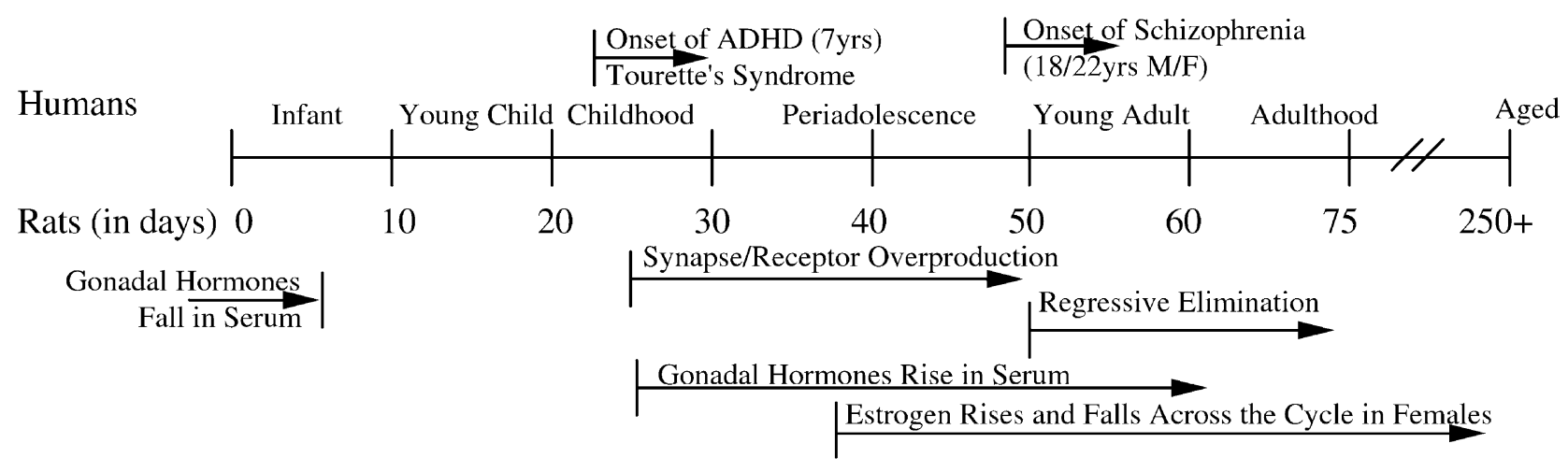

Fig. 2. A relative comparison of ages and stages of human versus rat development [12].

cortex peaks at 6 months of age [99], but peaks at 2 years of age in the prefrontal cortex [98]. Similarly, Lewis and colleagues $[16,179]$ demonstrated differences in the magnitude of change in tyrosine hydroxylase immunoreactivity for different cortical areas; laminar changes exist within regions as well [135]. Comparable results are reported with magnetic resonance imaging (MRI) of gray matter in humans [72,74, 75]. Finally, cortical changes occur later than subcortical changes in overproduction and elimination [15].

These anatomical changes parallel the functional development of each region, with marked differences in time course for cortical and subcortical regions [15,209]. For example, changes in the morphology of dopaminergic neurons occur with a similar time course as the peak of dopamine content in the cortex [77]. Similarly, alterations in synaptic density parallel density changes in receptor density for a number of neurotransmitter systems [138]. Functionally, motor development occurs earlier than cognitive development and parallels the ontogeny of the striatum and cortex, respectively [15,224].

One of the greatest transitions during adolescence, however, is in the development of abstract reasoning and affect and its regulation [19,195]. Here, the clinical knowledge has surpassed our preclinical knowledge, in part because of the difficulties of modeling such complex behaviors in animals. To date, information based on longitudinal fMRI studies have led Casey et al. [38] to hypothesize that the maturation of cognition parallels the synaptic elimination phase. Future longitudinal fMRI studies will yield important information about the development of the amygdala, hippocampus, and cingulate gyrus as it relates to affect. To conclude, the maturation of motor behavior, cognition and affect is integrally related to synaptic remodeling or enhanced connectivity that occurs before adulthood.

\section{Intrinsic factors of brain development}

A number of functional changes occur during the maturation of the brain that serve as important regulators or stabilizers of programmed development [101].
In addition to the structure-function relationships described above, age-dependent changes in intrinsic factors are integral for determining set points in synaptic activity that further define a developmental trajectory. Four categories exist: (1) neurotransmitters serve as trophic factors that directly guide innervation; (2) neurotransmitters work indirectly by altering the transient expression of certain markers; (3) pharmacological sensitivity varies dramatically across age; and (4) underlying sex differences. Thus, alterations within any of these categories during the titration of a set point of function could modify function later in life in a way that would differ from a similar insult during adulthood.

\subsection{Neurotransmitters themselves serve trophic functions in the brain}

Changes in neurotransmitter levels produce regionalselective changes indirectly via their trophic actions during development. Appropriate stimulation during a critical period of development is necessary for normal maturation, while inappropriate stimulation during these transitions causes abnormal development [227]. For example, dopamine [70,107,125,203,216] and serotonin [123,126,228] have trophic roles early in development (including neuroblast division, cell migration, and synapse formation). Dopamine increases neuronal branching and outgrowth [216] via the D2 receptor family [202]. Furthermore, activation of D1 dopamine receptors inhibits growth cone motility [125]. These plastic effects are found only during a pre-pubertal window of opportunity [203].

\subsection{Transient receptor expression guides innervation}

Transient expression of receptors and/or function during early postnatal life is believed to play a guiding/trophic role for innervation. These receptors/functions are expressed for a discrete period developmentally and then become virtually absent from the adult brain [46]. For example, the serotonergic 5-HT7 receptor is transiently expressed in striatum before 15 days and is virtually absent by 21 days and adulthood [221]. Almost in parallel, serotonin 
immunoreactive varicosities increase synaptic formation between birth and 14 days of age, fall at 21 days, but subsequently increase to adult levels [53]. In the latedeveloping cortex [77], serotonin innervation prunes to adult levels after puberty. At this stage it is not clear, however, whether these changes in serotonin serve a guiding/trophic function in brain development, or whether marked neuronal overproduction has its own functional adaptations. Furthermore, transient expression of receptors is not limited to membrane-bound receptors. Nuclear estrogen receptors are detectable in layer $\mathrm{V}$ of the rat auditory cortex between 7 and 15 days of age in the rat, and other cortical areas as well [232]. Furthermore, transient neuronal projections exist [90].

Transient pharmacological function also occurs during development. A transient synthesis-modulating autoreceptor in the prefrontal cortex is present pre-pubertally, but absent post-pubertally [8,207,211]. Furthermore, experiments utilizing tetrodotoxin in cortical slices suggest the presence of a stimulatory interneuron that wanes during adolescence [207]. This transient functional activity may be indicative of an underlying trophic role of dopamine into this region, but this is not known with certainty yet. Retention or stabilization of these factors can program a given brain region along a different developmental trajectory; this is discussed further in Sections 4 and 5.

\subsection{Age-dependent differences in pharmacological sensitivity to drugs}

Pharmacological profiles change dramatically with age, and allow neurotransmitters greater or lesser range to influence their own development. The determination of set points for future regulation and pharmacological sensitivity occurs pre-pubertally and influences the overall tone of the mature neurotransmitter system. For example, dopamine pharmacology changes during the transitions from preweaning to puberty to adulthood in the rat $[8,11,146]$.

Pharmacological sensitivity changes with different maturational states for some, but not all, regulatory processes. Surprisingly, the sensitivity of the release modulating autoreceptor that regulates this process does not change appreciably in response to dopamine agonists [9, $10,48,69]$. However, maturational differences in dopamine release modulation appear under conditions of elevated activity [10], and in response to dopamine antagonists [11]. TheED50s for the disinhibitory autoreceptor response (i.e. an increase in dopamine release) to either the D2 antagonist sulpiride [11] or haloperidol [36] decline as much as 75 times with maturation [35]. However, under depolarized conditions, dopamine release is actually inhibited at 21 days and adulthood, but not at 5, 10, or 15 days following D2 receptor antagonism [11]. We have hypothesized that this phenomenon is akin to depolarization block as theorized by Grace [81], and may provide an additional protective mechanism against pathological stimulation in older animals that is not present earlier.

Synthesis regulation also shows an idiosyncratic profile of maturation, with an abrupt loss of function in adolescence. Synthesis autoreceptors have exquisite sensitivity in the striatum, accumbens and the prefrontal cortex as early as 10 days of age [8] that wanes dramatically during the onset of adolescence (at approximately 40 days) and becomes adult-like in the accumbens and striatum [30]. To illustrate this point, estimates of the Inhibitory Dose of $50 \%$ of the maximum effect (ID50) are found in Table 1. Cortical synthesis regulation is absent by adulthood [211].

Pharmacological transitions are another distinct characteristic of adolescence relative to other ages. Extracellular levels of dopamine are significantly reduced at this stage of development relative to younger and older ages [9]. Pinnacle levels of locomotor activity during adolescence [200] parallel changes in cyclic AMP levels [4] more closely than changes in dopamine receptor density or levels [13]. Furthermore, blunted behavioral responses to stimulants reported during the adolescent period [128,196] are mirrored in blunted pharmacological response to D1 and D2 agonists at the level of cAMP [4]. One possibility for this blunting of pharmacological responsiveness may be related to increases in gonadal hormones during adolescence. These hormonal changes, in turn, may shift subcortical to cortical dopamine hyperactivity during adolescence and adulthood [4].

Stress responsiveness also dramatically changes during development. Stress-mediated changes within the dopamine system have a wider magnitude of effect during development than adulthood. Before puberty, the beta-carboline FG-7142, an agent that has stress-like effects on dopamine $[31,50]$, increases neuronal activation (indicated by c-fos immunoreactivity changes) in accumbens to a greater extent than the adult-typical response of predominant prefrontal cortex activation [146]; these data are shown in Fig. 3. We have used this finding to possibly explain developmental differences in how children handle stress (an increase in activity) compared with adults (a much more 'cognitive' event). Mechanistically, the stress-effectors also change dramatically early in postnatal life. Fetal rats have high basal blood levels of corticosterone that respond to multiple stressors [186]. Between 2 and 14 days of age,

Table 1

ID50s $(\mathrm{mg} / \mathrm{kg})$ for synthesis inhibition in vivo by $\pm 7-\mathrm{OH}-\mathrm{DPAT}$ in striatum, nucleus accumbens, and prefrontal cortex of developing rats (from Ref. [8])

\begin{tabular}{llll}
\hline Age (days) & Striatum & Nucleus accumbens & Prefrontal cortex \\
\hline 10 & $\ll 0.1$ & $0.267 \pm 0.20$ & $\ll 0.1$ \\
15 & $0.488 \pm 0.32$ & $1.415 \pm 0.46$ & $0.794 \pm 0.43$ \\
20 & $0.405 \pm 0.14$ & $0.953 \pm 0.21$ & $2.969 \pm 0.12$ \\
40 & $2.460 \pm 0.25$ & $3.533 \pm 0.64$ & - \\
\hline
\end{tabular}




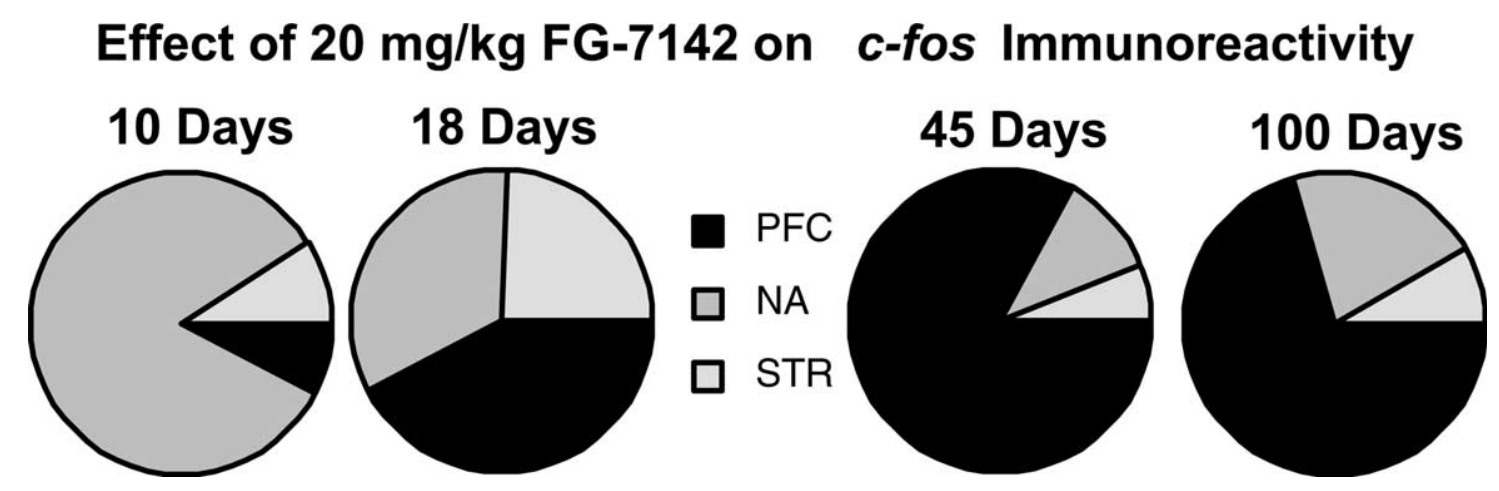

Fig. 3. The percentage of c-fos immunopositive neurons that respond to FG-7142 during development in the rat[146]. Immature and mature rats were administered $20 \mathrm{mg} / \mathrm{kg}$ FG-7142, a pharmacological stressor, and the number of c-fos immunopositive neurons were quantified in the prefrontal cortex, nucleus accumbens, and the striatum.

corticosterone levels decline and are paralleled by a decrease in responsiveness to some [186], but not all [121, $132,166,168]$, stressors within the hypothalamic-pituitary adrenal (HPA) axis. This period is known as the stress hyporesponsive period (SHRP). These changes are believed to be vitally important for programming the HPA axis [168], and possibly the dopamine system, to stress-related events in the environment.

Taken together, differences in neuroanatomy and pharmacological sensitivity during maturation set the stage for different periods of vulnerability to insult. The dramatic rearrangements in structure and function that characterize adolescence represent a turning point in how the brain deals with exogenous or pathological stimulation. That is, prepubertal influences are incorporated into the maturation of anatomy and function as it determines set points for adult function. Stress, for example, would potentially have a greater impact on the development of sub-cortical rather than cortical structures and set the stage for schizophrenia [224].

\subsection{Sex differences in brain development}

Aside from regional-dependent changes in synapse/receptor overproduction and elimination, sex-dependent changes are also observed during development. We first reported that D1 and D2 receptors are overproduced and eliminated by as much as $40 \%$ in the striatum of male, but not female, rats during adolescence [13]. D1 and D2 receptor density was not different across sexes by adulthood in the striatum, but D1 receptor density in the accumbens was significantly higher in males than females. The observed overproduction of receptors is not controlled by the pubertal surge in gonadal hormones, as neither castration nor oviarectomy influenced their expression [6]. These data point to the importance of early hormonal experience in determining maturational changes in the dopamine system.

Behaviorally, animal studies show that females are significantly more active in open-field experiments than males [23,199,201,229]. After the periadolescent period, activity levels decline by half in the males, but only a mere $10 \%$ in females $[199,201]$. Running wheel activity is cyclical in females, reaching its pinnacle when estrogen levels are low and its nadir when estrogen levels are elevated [225]. This increased activity in adolescent females is attributed to the postnatal organizing effects of gonadal steroid exposure that are activated around puberty [193,200].

Similar sex differences in overproduction and elimination of gray and white matter in the human brain are reported [72, 75]. Girls reach peak levels of gray matter earlier than males (11.6 versus 12.8 years, respectively), but again, regionally specific changes are noted. Males have an overall $8-9 \%$ larger total cerebral and cerebellar volume than females [47, 74]. Volume of the left amygdala increases significantly in males, whereas the right hippocampus increases significantly in females [75]. The relative volume of the putamen and the globus pallidum is larger in males, but the caudate is larger in females. The size of the caudate and the putamen subsequently decrease with age in males only. Many of these sex differences persist into adulthood [79].

Age and sex differences in myelination are also observed, in which the development of white matter is inversely related to gray matter [73]. Myelination of the corpus callosum [170] and other structures [27] continues well into the third decade of life, with males often lagging behind females in this process. This sex differences appears in childhood, where developmentally, the rate of myelination within the corpus callosum is greatest during childhood and decreases thereafter [111]. By adulthood, however, males have larger corpus callosum subregions in the genu and anterior body than females [230]. Once formed, myelin does not appear to fine-tune, as it is not pruned at any age that we know.

\subsection{Clinical implications of age and sex related changes in brain development}

Overproduction and elimination of synapses, receptors, and function is the mechanism by which the brain fine-tunes itself in order to achieve its adult topography. 
The overproduction phase is hypothesized to maximize the information-carrying capacity of the immature brain. With the onset of puberty, and thus pruning, synaptic efficacy is streamlined [63,224] in a regionally specific manner. Similarly, pharmacological sensitivity stabilizes after puberty, but pre-pubertal transitions aid in the determination of proper physiological set points that match the demands of the environment. Hormonal changes are hypothesized to aid in the transition of subcortical hyperactivity/cortical hypoactivity during childhood to the reverse during adolescence and young adulthood and could explain the appearance of primarily motoric symptoms during childhood, followed by more psychotic sympomotology in adolescence and adulthood [224]. Thus aberrancies in this mechanism have been proposed to result in schizophrenia [63,93,112], and more recently, TS and ADHD [14,208,209].

Taken together, differences in neuroanatomy, pharmacological sensitivity, and sex during maturation set the stage for unique periods of vulnerability to insult. The dramatic rearrangements in structure and function that characterize adolescence represent a turning point in how the brain deals with exogenous or pathological stimulation. That is, prepubertal influences are incorporated into the maturation of anatomy and function as it determines set points of physiological function. Pertubations during this process will subsequently reveal themselves after the initiation of puberty or adrenarche as hormone levels rise [164].

\section{Extrinsic factors of brain development}

The sculpting of the immature brain is an interactive process between genetic programming, cell function, and the environment. The result of this process is an endophenotype, which refers to heritable traits that increase the risk to develop or manifest a given disease [39], and offers a new approach to elucidating the underlying mechanisms of action of common symptoms across disorders [3]. For example, the endophenotypes of ADHD consist of aberrancies in temporal processing or delay gradients [39]. As a result of such categorization, hypotheses about the 'input' (the underlying brain mechanisms that are involved) as well as the 'output' (the behavioral manifestation) permit a broader evaluation of relevant risk factors. At this juncture, we have already discussed normal developmental trajectories (part of the input). The remaining portion of this review will present available evidence for how various known risk factors impact this process to produce a behavioral phenotype (part of the output). Taken together, evidence for how the same etiological risk factors produce different phenotypes will illustrate the importance of points of vulnerability (or windows of opportunity) of brain development.

Key risk factors for the expression or modulation of psychopathology include exposure to drugs, stress, hypoxia/ischemia, viral infection, and gonadal steroids. The action of some of these factors will be discussed as they influence trajectories of brain development via direct or indirect actions on the development of their own systems [227].

\subsection{Experience-expectant and experience-dependent development}

The terms 'experience-expectancy' and 'experiencedependency' first were presented by Black and Greenough [82]. In this seminal paper, they articulated how the environment can have differential effects on the final adult topography as it relates to the development of the normal trajectory of brain development. Both qualitative and quantitative differences in environmental stimuli can alter brain maturation depending on the timing of the insult, the stage of assessment, and the brain region of interest. Keeping in mind that development is full of abrupt transitions (e.g. the overproduction and elimination of synapses and receptors, functional changes, and transient effects of transmitters and hormones), it is easier to understand how the timing of numerous insults is instrumental for the unique expression of a deficit or injury later in life.

\subsubsection{Experience-expectant development}

Experience-expectant development incorporates environmental stimuli into the normal pattern of neuronal development. This process involves a critical period, when appropriate stimulation is required for normal development $[149,171,233]$. Developmental critical periods refer to events earlier in life that have a significantly greater impact than the same event later in life [171] rather than an 'all-ornone' process as previously conceptualized. The classic example is the necessity of visual stimulation on the development of ocular dominance columns [97], which has provided a body of information about how synaptic activity sculpts brain morphology by its influence on neuronal survival. Three crucial components for activity-dependent plasticity exist: (1) a critical period for neuroanatomical rearrangements $[66,96,97]$; (2) 'use it or lose it', in which the remaining inputs expand into enucleated projection sites [76,173,198]; and (3) the necessity of a number of factors, including the $n$-methyl-D-aspartate (NMDA) receptor system [65], the neurotrophin BDNF [89], GABA [61], class I major histocompatability (I MHC) genes [41], and modulatory neurotransmitter systems, especially serotonin [218]. Disruption of any of these components during key periods demonstrates their involvement in an experienceexpectant manner.

\subsubsection{Experience-dependent development}

Experience-dependent development involves the incorporation of unique information into neuronal patterns. This process involves a sensitive period, when stimuli may 
impinge on development to produce a characteristic effect specific to the maturational stage of insult. Such stimuli include drugs, stress, toxins, infection, or hypoxia/ischemia. Interference of the immature neuronal milieu during a sensitive period alters future neuronal function and will be discussed in depth in Section 5.

\subsection{Imprinting and epigenetic factors}

Imprinting describes the long-lasting effects that endure well after the removal of the originating agent $[91,130]$. On a molecular level, imprinting of epigenetic factors, i.e. those that have a heritable influence on chromosome or gene function without changes in gene structure [136], occurs at various levels of structure and function. Epigenetic factors undoubtedly play a large role in the expression of a number of neuropsychiatric illnesses, given that concordance rates do not reach $100 \%$ in monozygotic twin studies. Epigenetic factors can serve as the original impetus for a disorder, as in fetal alcohol syndrome, or play a permissive role in the expression of a disorder [62,217].

Early in life, genomic imprinting is the process by which epigenetic influences alter the expression of an allele [21]. Genomic imprinting occurs during two main stages of development: during the differentiation of germ cells and in post-implantation of the embryo, thus influencing the function of cell types during different periods of development [178]. The process works by either DNA methylation or by histone acetylation or methylation and regulates gene expression by blocking transcription regulatory factors, repressing gene expression, or regulating transcription activity [136]. As a result of genomic imprinting, any one of approximately 50 genes associated with either paternal (androngenetic) or maternal (parthogenetic) transmission can be silenced [21] and influence the development of psychopathology [113]. Genes that are maternally influenced are found in the cortex, striatum, and hippocampus and are involved in increasing brain growth; genes that are paternally influenced are found primarily in the hypothalamus, septum, preoptic area, and the bed nuclei of the stria terminalis and are involved in retarding brain growth [114]. Allele-specific changes in expression can be polymorphic, incomplete, or tissue-specific. As a result, penetrance for these genes can vary.

Later in life, gene and environmental interactions play themselves out more directly than discussed above, and is encompassed in the field of epigenomics [162]. However, it is often the case that phenotypic expression is delayed for psychiatric illnesses [45,148,204]. For example, prominent theories for schizophrenia include a combination of structurally unstable DNA that is vulnerable to either acquired or inherited epigenetic influences [108,165]. Similarly, underlying genetic vulnerability is proposed for drug addiction [160]. The environmental factor of stress can cause the genetic liability of both disorders to come to light, with earlier stress exposure resulting in a greater likelihood of expression. Therefore, it is often the unique combination of genetic vulnerability and the maturational stage of exposure that differentially determines the enduring impact of similar environmental factors (discussed below in Section 5) on developmental trajectories [177].

\section{Extrinsic factors known to influence the vulnerability to insult}

This section will highlight supportive data regarding the importance of a number of factors that influence the appearance of any early insult.

\subsection{The importance of timing}

The enduring impact of an early insult depends on the maturational stage of exposure such that perturbations in the synaptic milieu redirect the normal developmental trajectory. Specifically, the immature organism adapts by incorporating environmental information permanently into the mature structure and function (Fig. 1). In contrast, the mature organism compensates to accommodate changes in the environment. Despite a burgeoning literature documenting age-dependent changes following exposure to various epigenetic factors (reviewed below), we are now beginning to appreciate the potentially enhanced vulnerability of the pre-pubertal brain to the long-lasting effects of early insult [7]. Alternatively, the time before puberty may represent a window of opportunity to redirect aberrant development back onto a normal trajectory.

The full imprinted effect of early drug exposure transitions through development, with the long-term effects often opposite to those observed following adult drug exposure. These transitions are illustrated in a simple model in Fig. 4. Drugs like neuroleptics [180], marijuana and nicotine [67], alcohol, and stimulants [7] have delayed effects that are not apparent until adolescence or later [118]. The adaptive processes underlying these changes is not necessarily qualitatively different than that proposed in the allostasis model of drug abuse [117]. However, quantitatively, these adaptations are far more reaching and permanent following early exposure compared with later exposure to the same drug.

The expression of monoamine receptors and function are programmable, meaning that it follows the adage use it or lose it, and demonstrates how the timing of extrinsic factors can be expressed in a developmentally dependent manner. For example, prenatal and postnatal D2 receptor antagonism with haloperidol decreases D2 expression, behavioral responsiveness to apomorphine and amphetamine, autoreceptor sensitivity, and adenylate cyclase activity [131, $180,187,197]$. These findings are opposite to what is found following adult chronic neuroleptic exposure [181]. Similarly, early manipulations of dopamine levels can reduce D1 
a. Juvenile Drug Exposure

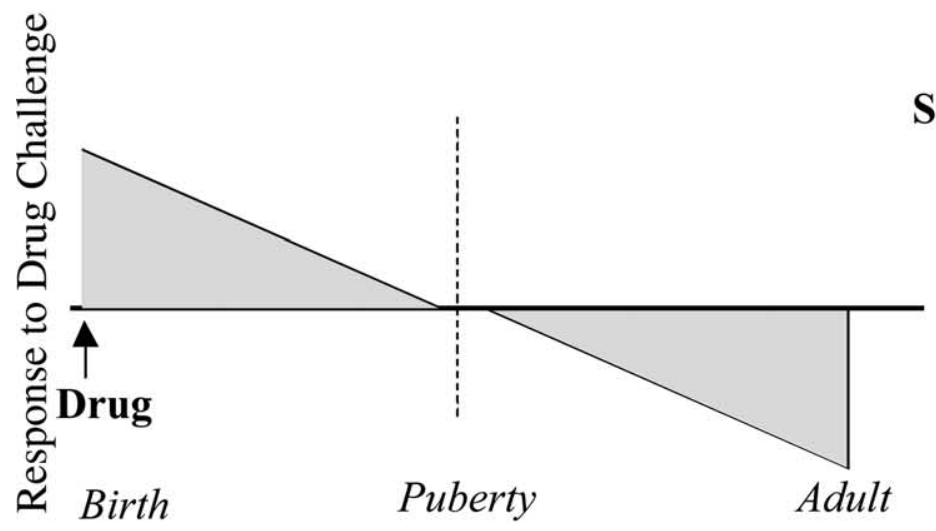

b. Adult Drug Exposure

Fig. 4. Diagram of different trajectories of stimulant responsiveness depending on the maturational stage of exposure: (a) pre-pubertal drug exposure (left) may (or may not) produce an initial sensitized response [128] that wanes with time and manifests as decreased sensitivity (tolerance) after puberty (b) post-pubertal drug exposure (right) produces sensitization that increases with time.

and D2 receptor expression [119] in a reversible manner [70]. Again, these developmental findings are completely opposite to the well-known effects of these agents during adulthood, and receptor antagonism leads to receptor upregulation or supersensitivity [44].

Very little data is available on the developmental effects of chronic administration of agonists (the 'use it too much' phenomenon) during early development. Prenatal exposure to cocaine permanently alters neuronal migration and innervation patterns $[133,137]$ that in turn, may underlie functional changes [194]. Postnatal exposure to cocaine ( $25 \mathrm{mg} / \mathrm{kg}$; between 1 and 10 days of age) elevates extracellular dopamine levels at 10 and 21 days that return to control values by 35 days [95]. These changes are accompanied by an abnormal distribution of striatal D2 receptor mRNA.

The most dramatic changes following postnatal drug exposure are delayed in their expression and appear after puberty. Chronic administration of the stimulant methylphenidate $\left(\right.$ Ritalin $^{\mathrm{TM}}$ ) before puberty (between 20 and 35 days) or after puberty (between 50 and 65 days) produces different responses to cocaine challenge following a 25-day withdrawal period [7]. Pre-pubertal exposure to methylphenidate increases the aversive properties to cocaine and reduces locomotor responsiveness to cocaine. DowEdwards and colleagues report similar behavioral results following pre-pubertal exposure to cocaine [55-57]. Moreover, methylphenidate-induced behavioral changes were accompanied by an increase in the transcription-regulating factor, cyclic AMP regulating binding protein (CREB), and suggest a long-term genetic modification [7]. In contrast, it is well known that post-pubertal [32] or adult exposure to stimulants increases responsiveness to later challenge [68, $120,127,157,158,206]$. Clinically, these results support the observation by Biederman et al. [28] of reduced SUD in adolescents with ADHD that had received pharmacotherapy during childhood relative to untreated adolescents with
ADHD. Taken together, these results suggest that dopamine tone set prior to adolescence determines the fate of the synaptic milieu during adulthood-but in this case, these data suggest that a window of opportunity exists for reducing risk later in life.

Serotonin is also vulnerable to environmental insults during development. The most extensive literature that documents postnatal exposure to increased serotonin levels is found in the clomipramine model of depression [222]. By name alone, this model is associated with behavioral changes, including decreased latency for the forced swim test [219], circadian rhythm blunting [223], increased anxiety [5], as well as neurochemical changes [5] that are consistent with clinical symptoms of depression later in life. Taken together, pre-pubertal drug exposure produces behavioral, neurochemical, and molecular alterations that differ from the alterations observed following post-pubertal drug exposure.

\subsection{The age of assessment}

The expression of imprinted effects of an early insult depends on the stage of maturation that they are assessed [7, 197]. For example, prenatal exposure to haloperidol results in a hyposensitive, no change, or a hypersensitive locomotor response to amphetamine when assessed in weanlings, adolescent, and adult rats, repectively [197]. Stimulants produce an initial sensitization response immediately following exposure [128], but reverse sensitization later in life [7]. Reduced serotonin levels between 10 and 20 days of age in the rat decreases hippocampal innervation at 30 days that reverses by 62 days [150]. Thus, the timing of assessment is vitally important to our understanding of early insult.

The effects of early insults are often delayed after the onset of puberty, suggesting an interactive process between deficit and development $[25,26,33,226]$. For example, direct 
lesions of the hippocampus early in life produce postpubertal symptoms that are consonant with schizophrenia [141]. Specifically, deficits in pre-pulse inhibition [143], enhanced sensitivity to stress [142], and pharmacological responsiveness [144] are not apparent until after day 56 in this animal model.

\subsection{Regional selectivity of insult}

The effect of an early insult is an interactive process between location of neurotransmitters and receptors and their functional state for their given stage of maturation. As reviewed above in Sections 2 and 3, age-related fluxes within the target of the insult could dramatically impact the expression of the insult in ways that are not predictable from what we know from adult studies. For example, it is well accepted that the high density of glucocorticoid receptors in the hippocampus and cerebellum is integrally important for enhanced vulnerability to stress in these regions. However, as described in Section 3.3 above, stress has more widespread effects earlier in development (Fig. 3) [146]. As a result, early stress can imprint on the subcortical dopamine systems to a greater extent within this prepubertal window than post-pubertal exposure to stress.

\subsection{Dose-dependency issues of early insults}

Most drugs exert their effects in a dose-dependent manner. At this stage, we know little about long-term exposure to most medications primarily because it is difficult to dissect disease process from medication effects. Preclinical studies suggest a non-linear relationship between drug exposure and enduring effects on structure and function. For example, low concentrations, 5-methoxytryramine $(0.1-100 \mu \mathrm{M})$ inhibits serotonin uptake binding, whereas higher concentrations augment binding [191,228]. In culture, reduced serotonin increases dendritic branching at distal, but not proximal branch points, while augmented serotonin decreases neuronal branching [51].

The effects of stress can be dose-dependent as well. Exposure to stress within a normal physiological range promotes synaptic plasticity, whereas pathological levels lead to impaired development of structure and function [18]. Evidence from the preclinical literature on the effects of early maternal separation as a species-relevant stressor (reviewed in Refs. [49,220]) suggest that glucocorticoids and corticotrophin releasing hormone $(\mathrm{CRH})$ are integrally involved in programming HPA activity for life [140,184].

\subsection{The influence of sex as an important variable for the expression of early insult}

An important, and often overlooked, facet of environmental influences is the relationship between sex and early insult. Steroid hormones can have two main effects. The first role occurs early in life and directs the differentiation of the brain. Specifically, cells are born, differentiate, migrate, or die depending on the hormonal environment in a sexdependent manner [151,215]. This hormonal environment can have dramatic (take the sexual dimorphic nucleus as an example), or subtle (differential isoform expression of $\mathrm{D}_{2}$ long versus the $\mathrm{D}_{2}$ short dopamine receptor messenger RNA [85,122]) influences on overall neuronal function. Such sex-dependent differences can, in turn, underlie sexdependent differences in the expression of an illness or medication effects.

The second role of steroid hormones appears during puberty when gonadal and adrenal hormones increase [92]. Behavioral transitions parallel changes in gonadal and adrenal hormone changes during adrenarche [164,182]. Gonadal hormones influence behavior directly for reproduction [1] or indirectly via their interactions with neurotransmitter systems [22,24,152]. Gonadal hormones modulate neurotransmitter effectiveness via membranebound estrogen receptors [152,155,214], which exert their effects non-genomically to alter $\mathrm{G}$ protein activity $[52,145$, 231]. It is at this stage that the functional expression of an earlier insult emerges as hormonal changes influence the pharmacological sensitivity in such a way so as to unmask any deficit. As noted above, the waning or emergence of various psychiatric illnesses parallels these pubertal changes.

In summary, we do not know how early insult interacts with sex and gonadal hormones to produce sex-dependent effects. Yet, we know that sex differences are observed in a number of clinically relevant animal models, including drug exposure [5,57] and hypoxia/ischemia (Boksa, this journal; $[60,169,205]$. It is possible that early insult alters gonadal hormone expression or function $[59,153]$, or alternatively, hormones alter the nature of the insult [2].

\section{Conclusions}

The relationship between early insult and resulting psychopathology is still in its infancy. Waves of overproduction and elimination of synapses, receptors, and function may serve as a neural guide or stabilization mechanism during adolescence [101]. Thus, the key to understanding the impact of various risk factors on the emergence of psychopathology is the time course of development of the underlying brain structures and function. In this regard, we know very little about how the brain matures from childhood to adolescence. Clearly, the prepubertal brain is extremely plastic, but with this enhanced plasticity, comes enhanced vulnerability that is not fully observable until well after the time of insult during adolescence or adulthood. Whether the onset of puberty signifies the closing of a window of opportunity for altering trajectories has yet to be determined. Literature from the effects of early stress exposure [88] and stimulant exposure 
[7,55-57] imply that this may indeed be the case, but a more refined time course is needed to make this assertion.

The potential clinical implications for treatment, including long-term exposure to medications or early intervention during abuse, during childhood need to be considered. Clinicians treating young children with psychotropic drugs need to make a difficult decision weighing the potential benefits of treatment versus unknown consequences of exposure of the immature brain to drugs that may exert enduring effects on brain development. While not reviewed comprehensively here, stress also significantly impacts developmental trajectories that are involved in various psychiatric disorders [2], including schizophrenia, depression, drug abuse, and a myriad of other psychiatric disorders [109]. New frontiers in early intervention need to embrace the fact that the immature brain incorporates information into its structure and function differently than the mature brain. Novel treatment strategies should be directed at restoring the disordered trajectory along a normal course, rather than treating symptoms. Based on the review provided here, an increased appreciation of both intrinsic and extrinsic factors during the developmental process and its response to insult should be used to guide future understanding of the nature of illness and insult and its future treatment.

\section{Acknowledgements}

The author wishes to thank Carryl P. Navalta and Kai C. Sonntag for valuable comments and Martin H. Teicher for his continued support (MH-43474). The financial support of the Scottish Rite Schizophrenia Research Program, the Tourettes Syndrome Association, and NARSAD (SLA) is also gratefully acknowledged.

\section{References}

[1] Allen LS, Gorski RA. Sexual orientation and the size of the anterior commissure in the human brain. Proc Natl Acad Sci USA 1992; 89(15):7199-202.

[2] Allen NB, Lewinsohn PM, Seeley JR. Prenatal and perinatal influences on risk for psychopathology in childhood and adolescence. Dev Psychopathol 1998;10(3):513-29.

[3] Almasy L, Blangero J. Endophenotypes as quantitative risk factors for psychiatric disease: rationale and study design. Am J Med Genet 2001;105(1):42-4.

[4] Andersen S. Changes in the second messenger cyclic AMP during development may underlie motoric symptoms in attention deficit/ hyperactivity disorder (ADHD). Behav Brain Res 2002;130: 197-201

[5] Andersen S, Dumont N, Teicher M. Differences in behavior and monoamine laterality following neonatal clomipramine treatment. Dev Psychobiol 2002;41:50-7.

[6] Andersen S, Thompson A, Krenzel E, Teicher M. Pubertal changes in gonadal hormones do not underlie adolescent dopamine receptor overproduction. Psychoneuroendocrinology 2002;27(6):683-91.
[7] Andersen SL, Arvanitogiannis A, Pliakas AM, LeBlanc C, Carlezon $\mathrm{Jr}$ WA. Altered responsiveness to cocaine in rats exposed to methylphenidate during development. Nat Neurosci 2002;5(1): 13-14.

[8] Andersen SL, Dumont NL, Teicher MH. Developmental differences in dopamine synthesis inhibition by 7-OHDPAT. Naunyn Schmiedeberg's Arch Pharmacol 1997;356:173-81.

[9] Andersen SL, Gazzara RA. The ontogeny of apomorphine-induced alterations in dopamine release: I. Effects on spontaneous release. J Neurochem 1993;61:2247-55.

[10] Andersen SL, Gazzara RA. The development of D2 autoreceptormediated modulation of $\mathrm{K}(+)$-evoked dopamine release in the neostriatum. Brain Res Dev Brain Res 1994;78(1):123-30.

[11] Andersen SL, Gazzara RA. Effects of (-) sulpiride on dopamine release in striatum of developing rats: degree of depolarization influences responsiveness. J Neurochem 1996;67:1931-7.

[12] Andersen SL, LeBlanc CJ, Lyss PJ. Maturational increases in c-fos expression in the ascending dopamine systems. Synapse 2001;41(4): 345-50.

[13] Andersen SL, Rutstein M, Benzo JM, Hostetter JC, Teicher MH. Sex differences in dopamine receptor overproduction and elimination. Neuroreport 1997;8(6):1495-8.

[14] Andersen SL, Teicher MH. Sex differences in dopamine receptors and their relevance to ADHD. Neurosci Biobehav Rev 2000;24(1): 137-41.

[15] Andersen SL, Thompson AT, Rutstein M, Hostetter JC, Teicher MH Dopamine receptor pruning in prefrontal cortex during the periadolescent period in rats. Synapse 2000;37(2):167-9.

[16] Anderson SA, Classey JD, Conde F, Lund JS, Lewis DA. Synchronous development of pyramidal neuron dendritic spines and parvalbumine-immunoreactive chandelier neuron axon terminals in layer III of monkey prefrontal cortex. Neuroscience 1995;67: 7-22.

[17] Association AP. Diagnostic and statistical manual for mental disorders, 4th ed. Washington, DC: American Psychiatric Press; 1994. DSM-IV

[18] Avishai-Eliner S, Brunson KL, Sandman CA, Baram TZ. Stressedout, or in (utero)? Trends Neurosci 2002;25(10):518-24.

[19] Baird AA, Gruber SA, Fein DA, Maas LC, Steingard RJ, Renshaw PF, Cohen BM, Yurgelun-Todd DA. Functional magnetic resonance imaging of facial affect recognition in children and adolescents. J Am Acad Child Adolesc Psychiatry 1999;38(2):195-9.

[20] Barks JD, Silverstein FS, Sims K, Greenamyre JT, Johnston MV. Glutamate recognition sites in human fetal brain. Neurosci Lett 1988;84:131-6.

[21] Beaudet AL, Jiang YH. A rheostat model for a rapid and reversible form of imprinting-dependent evolution. Am J Hum Genet 2002; 70(6):1389-97.

[22] Becker JB, Beer ME. The influence of estrogen on nigrostriatal dopamine activity: behavioral and neurochemical evidence for both pre- and postsynaptic components. Behav Brain Res 1986;19(1): 27-33

[23] Becker JB, Robinson TE, Lorenz KA. Sex differences and estrous cycle variations in amphetamine elicited rotational behavior. Eur $\mathbf{J}$ Pharmacol 1982;80:65-72.

[24] Bedard PJ, Malouin F, Dipaolo T, Labrie F. Estradiol TRH and striatal dopaminergic mechanisms. Prog Neuropsychopharmacol Biol Psychiatry 1982;6(4-6):555-61.

[25] Benes FM. The role of stress and dopamine-GABA interactions in the vulnerability for schizophrenia. J Psychiatr Res 1997;31(2): 257-75.

[26] Benes FM. Emerging principles of altered neural circuitry in schizophrenia. Brain Res Brain Res Rev 2000;31(2-3):251-69.

[27] Benes FM, Turtle M, Khan Y, Farol P. Myelination of a key relay zone in the hippocampal formation occurs in the human brain during childhood, adolescence, and adulthood. Arch Gen Psychiatry 1994; 51(6):477-84 
[28] Biederman J, Wilens T, Mick E, Spencer T, Faraone SV. Pharmacotherapy of attention-deficit/hyperactivity disorder reduces risk for substance use disorder. Pediatrics 1999;104(2):e20.

[29] Bird HR, Canino G, Rubio-Stipec M, et al. Estimates of the prevalence of childhood maladjustment in a community survey in Puerto Rico. Arch General Psychiatry 1988;45:1120-6.

[30] Booth RG, Baldessarini RJ, Marsh E, Owens CE. Actions of (+/- )7-hydroxy- $N, N$-dipropylaminotetralin (7-OH-DPAT) on dopamine synthesis in limbic and extrapyramidal regions of rat brain. Brain Res 1994;662(1-2):283-8.

[31] Bradberry CW, Lory JD, Roth RH. The anxiogenic beta-carboline FG 7142 selectively increases dopamine release in rat prefronta cortex as measured by microdialysis. J Neurochem 1991;56(3): 748-52.

[32] Brandon CL, Marinelli M, Baker LK, White FJ. Enhanced reactivity and vulnerability to cocaine following methylphenidate treatment in adolescent rats. Neuropsychopharmacology 2001;25(5):651-61.

[33] Brixey SN, Gallagher 3rd BJ, McFalls Jr. JA, Parmelee LF. Gestational and neonatal factors in the etiology of schizophrenia. J Clin Psychol 1993;49(3):447-56.

[34] Broaddus WC, Bennett Jr. JP. Postnatal development of striatal dopamine function. I. An examination of D1 and D2 receptors, adenylate cyclase regulation and presynaptic dopamine markers. Brain Res Dev Brain Res 1990;52(1-2):265-71.

[35] Campbell A, Baldessarini R. Effects of maturation and aging on behavioral response to haloperidol in the rat. Psychopharmacology 1981;73:219-22.

[36] Campbell A, Baldessarini RJ, Teicher MH. Decreasing sensitivity to neuroleptic agents in developing rats: Evidence for a pharmacodynamic factor. Psychopharmacology 1988;94:46-51.

[37] Canuso CM, Goldstein JM, Green AI. The evaluation of women with schizophrenia. Psychopharmacol Bull 1998;34(3):271-7.

[38] Casey BJ, Giedd JN, Thomas KM. Structural and functional brain development and its relation to cognitive development. Biol Psychol 2000;54(1-3):241-57.

[39] Castellanos FX, Tannock R. Neuroscience of attention-deficit/ hyperactivity disorder: the search for endophenotypes. Nat Rev Neurosci 2002;3(8):617-28.

[40] Changeaux JP, Danchin A. Selective stabilization of developing synapses as a mechanism for the specification of neuronal networks. Nature 1976;264:705-12.

[41] Corriveau RA, Huh GS, Shatz CJ. Regulation of class I MHC gene expression in the developing and mature CNS by neural activity. Neuron 1998;21(3):505-20.

[42] Cousino K, Corwin E. Seeing the unexpected: how sex differences in stress responses may provide a new perspective on the manifestation of psychiatric disorders. Curr Psychiatr Rep 2002;4(6):441-8.

[43] Coyle JT, Campochiaro P. Ontogenesis of dopaminergic-cholinergic interactions in the rat striatum: a neurochemical study. J Neurochem 1976;27(3):673-8.

[44] Creese I, Burt DR, Snyder SH. Antischizophrenic drugs: chronic treatment elevates dopamine receptor binding in brain. Science 1977;196:326-8.

[45] Cyranowski JM, Frank E, Young E, Shear MK. Adolescent onset of the gender difference in lifetime rates of major depression: a theoretical model. Arch Gen Psychiatry 2000;57(1):21-7.

[46] Daval G, Verge D, Becerril A, Gozlan H, Spampinato U, Hamon M. Transient expression of 5-HT1A receptor binding sites in some areas of the rat CNS during postnatal development. Int $\mathrm{J}$ Dev Neurosci 1987;5(3): $171-80$

[47] De Bellis MD, Keshavan MS, Beers SR, Hall J, Frustaci K, Masalehdan A, Noll J, Boring AM. Sex differences in brain maturation during childhood and adolescence. Cereb Cortex 2001; 11(6):552-7.

[48] De Vries TJ, Mulder AH, Schoffelmeer AN. Differential ontogeny of functional dopamine and muscarinic receptors mediating presynaptic inhibition of neurotransmitter release and postsynaptic regulation of adenylate cyclase activity in rat striatum. Brain Res Dev Brain Res 1992;66(1):91-6.

[49] Dettling AC, Feldon J, Pryce CR. Early deprivation and behavioral and physiological responses to social separation/novelty in the marmoset. Pharmacol Biochem Behav 2002;73(1):259-69.

[50] Deutch AY, Lee MC, Gillham MH, Cameron DA, Goldstein M, Iadarola MJ. Stress selectively increases fos protein in dopamine neurons innervating the prefrontal cortex. Cereb Cortex 1991;1(4) 273-92.

[51] Diefenbach TJ, Sloley BD, Goldberg JI. Neurite branch development of an identified serotonergic neuron from embryonic Helisoma: evidence for autoregulation by serotonin. Dev Biol 1995;167(1): 282-93.

[52] Dieudonne M, Pecquery R, Dausse J, Giudicelli Y. Regulation of white adipocyte guanin nucleotide binding proteins $\mathrm{Gs}$ alpha and $\mathrm{Gi}$ alpha $1-2$ by testosterone in vivo: influence of regional fat distribution. Biochim Biophys Acta 1993;1176:123-7.

[53] Dinopoulos A, Dori I, Parnavelas JG. The serotonin innervation of the basal forebrain shows a transient phase during development. Brain Res Dev Brain Res 1997;99(1):38-52.

[54] Dorn LD, Chrousos GP. The neurobiology of stress: understanding regulation of affect during female biological transitions. Semin Reprod Endocrinol 1997;15(1):19-35.

[55] Dow-Edwards D, Mayes L, Spear L, Hurd Y. Cocaine and development: clinical, behavioral, and neurobiological perspectives-a symposium report. Neurotoxicol Teratol 1999;21(5): 481-90.

[56] Dow-Edwards DL. Preweaning cocaine administration alters the adult response to quipazine: comparison with fluoxetine. Neurotoxicol Teratol 1998;20(2):133-42.

[57] Dow-Edwards DL, Freed-Malen LA, Gerkin LM. Sexual dimorphism in the brain metabolic response to prenatal cocaine exposure. Brain Res Dev Brain Res 2001;129(1):73-9.

[58] Duman RS. Synaptic plasticity and mood disorders. Mol Psychiatry 2002;7(1):S29-S34.

[59] Edwards HE, MacLusky NJ, Burnham WM. The effect of seizures and kindling on reproductive hormones in the rat. Neurosci Biobehav Rev 2000;24(7):753-62.

[60] Engelbregt MJ, van Weissenbruch MM, Popp-Snijders C, Lips P, Delemarre-van de Waal HA. Body mass index, body composition, and leptin at onset of puberty in male and female rats after intrauterine growth retardation and after early postnatal food restriction. Pediatr Res 2001;50(4):474-8.

[61] Fagiolini M, Hensch TK. Inhibitory threshold for critical-period activation in primary visual cortex. Nature 2000;404(6774):183-6.

[62] Faraone SV, Doyle AE. The nature and heritability of attentiondeficit/hyperactivity disorder. Child Adolesc Psychiatr Clin N Am 2001;10(2):299-316. viii-ix.

[63] Feinberg I. Schizophrenia: caused by a fault in programmed synaptic elimination during adolescence? J Psychiatr Res 1982-3;17:319-34.

[64] Fishbein D. The importance of neurobiological research to the prevention of psychopathology. Prev Sci 2000;1(2):89-106.

[65] Fox K, Daw N, Sato H, Czepita D. Dark-rearing delays the loss of NMDA-receptor function in kitten visual cortex. Nature 1991; 350(6316):342-4.

[66] Fox K, Zahs K. Critical period control in sensory cortex. Curr Opin Neurobiol 1994;4(1):112-9.

[67] Fried PA. Marihuana use by pregnant women and effects on offspring: an update. Neurobehav Toxicol Teratol 1982;4(4):451-4.

[68] Gatley SJ, Meehan SM, Chen R, Pan DF, Schechter MD, Dewey SL. Place preference and microdialysis studies with two derivatives of methylphenidate. Life Sci 1996;58(24):L345-52.

[69] Gazzara RA, Andersen SL. The ontogeny of apomorphine-induced alterations of neostriatal dopamine release: effects on potassiumevoked release. Neurochem Res 1994;19(3):339-45.

[70] Gelbard HA, Teicher MH, Baldessarini RJ, Gallitano A, Marsh ER, Zorc J, Faedda G. Dopamine D1 receptor development depends on 
endogenous dopamine. Brain Res Dev Brain Res 1990;56(1): 137-40.

[71] Gelbard HA, Teicher MH, Faedda JG, Baldessarini RJ. Postnatal development of dopamine D1 and D2 receptor sites in rat striatum. Brain Res 1989;49:123-30.

[72] Giedd JN, Blumenthal J, Jeffries NO, Castellanos FX, Liu H, Zijdenbos A, Paus T, Evans AC, Rapoport JL. Brain development during childhood and adolescence: a longitudinal MRI study. Nat Neurosci 1999;2(10):861-3.

[73] Giedd JN, Rumsey JM, Castellanos FX, Rajapakse JC, Kaysen D, Vaituzis AC, Vauss YC, Hamburger SD, Rapoport JL. A quantitative MRI study of the corpus callosum in children and adolescents. Brain Res Dev Brain Res 1996;91(2):274-80.

[74] Giedd JN, Snell JW, Lange N, Rajapakse JC, Casey BJ, Kozuch PL, Vaituzis AC, Vauss YC, Hamburger SD, Kaysen D, Rapoport JL. Quantitative magnetic resonance imaging of human brain development: ages 4-18. Cereb Cortex 1996;6(4):551-60.

[75] Giedd JN, Vaituzis AC, Hamburger SD, Lange N, Rajapakse JC, Kaysen D, Vauss YC, Rapoport JL. Quantitative MRI of the temporal lobe, amygdala, and hippocampus in normal human development: ages 4-18 years. J Comp Neurol 1996;366(2): 223-30.

[76] Godement P, Salaun J, Metin C. Fate of uncrossed retinal projections following early or late prenatal monocular enucleation in the mouse. J Comp Neurol 1987;255(1):97-109.

[77] Goldman-Rakic PS, Brown RM. Postnatal development of monoamine content and synthesis in the cerebral cortex of rhesus monkeys. Brain Res 1982;256(3):339-49.

[78] Goldstein J, Seidman L, Goodman J, Koren D, Lee H, Weintraub S, Tsuang M. Are there sex differences in neuropsychological functions among patients with schizophrenia? Am J Psychiatry 1998;155: $1358-64$

[79] Goldstein JM, Seidman LJ, O’Brien LM, Horton NJ, Kennedy DN, Makris N, Caviness Jr VS, Faraone SV, Tsuang MT. Impact of normal sexual dimorphisms on sex differences in structural brain abnormalities in schizophrenia assessed by magnetic resonance imaging. Arch Gen Psychiatry 2002;59(2):154-64.

[80] Gooney M, Shaw K, Kelly A, O’Mara SM, Lynch MA. Long-term potentiation and spatial learning are associated with increased phosphorylation of TrkB and extracellular signal-regulated kinase (ERK) in the dentate gyrus: evidence for a role for brain-derived neurotrophic factor. Behav Neurosci 2002;116(3):455-63.

[81] Grace AA, Bunney BS, Moore H, Todd CL. Dopamine-cell depolarization block as a model for the therapeutic actions of antipsychotic drugs. Trends Neurosci 1997;20(1):31-7.

[82] Black JE, Greenough WT. Developmental approaches to the memory process, 2nd ed. Learning and memory, New York: Academic Press; 1991

[83] Grigoriadis S, Seeman MV. The role of estrogen in schizophrenia: implications for schizophrenia practice guidelines for women. Can J Psychiatry 2002;47(5):437-42.

[84] Guillin O, Diaz J, Carroll P, Griffon N, Schwartz JC, Sokoloff P. BDNF controls dopamine D3 receptor expression and triggers behavioural sensitization. Nature 2001;411(6833):86-9.

[85] Guivarc'h D, Vernier P, Vincent J. Sex steroid hormones change the differential distribution of the isoforms of the D2 dopamine receptor messenger RNA in the rat brain. Neuroscience 1995;69:159-66.

[86] Hafner H, Behrens S, De Vry J, Gattaz WF. Oestradiol enhances the vulnerability threshold for schizophrenia in women by an early effect on dopaminergic neurotransmission. Evidence from an epidemiological study and from animal experiments. Eur Arch Psychiatry Clin Neurosci 1991;241(1):65-8.

[87] Halbreich U, Kahn LS. Role of estrogen in the aetiology and treatment of mood disorders. CNS Drugs 2001;15(10):797-817.

[88] Hall FS. Social deprivation of neonatal, adolescent, and adult rats has distinct neurochemical and behavioral consequences. Crit Rev Neurobiol 1998;12(1-2):129-62.
[89] Hanover JL, Huang ZJ, Tonegawa S, Stryker MP. Brain-derived neurotrophic factor overexpression induces precocious critical period in mouse visual cortex. J Neurosci 1999;19(22):RC40.

[90] Hattori T, Takada M, Moriizumi T, Campbell KJ. Direct striatothalamic projections in the neonatal rat. Brain Res Dev Brain Res 1990;54(1):137-41.

[91] Hess EH. The natural history of imprinting. Ann NY Acad Sci 1972; 193:124-36.

[92] Hiort O. Androgens and puberty. Best Pract Res Clin Endocrinol Metab 2002;16(1):31-41.

[93] Hoffman RE, Dobscha SK. Cortical pruning and the development of schizophrenia: a computer model. Schizophr Bull 1989;15:477.

[94] Holden C. Mental health. Global survey examines impact of depression. Science 2000;288(5463):39-40

[95] Howard SG, Fisher R, Landry CF. Alterations in the spontaneous release of dopamine and the density of the DA D2 receptor mRNA after chronic postnatal exposure to cocaine. Brain Res Bull 1997; 43(1):101-6.

[96] Hubel DH, Wiesel TN. The period of susceptibility to the physiological effects of unilateral eye closure in kittens. J Physiol 1970;206(2):419-36.

[97] Hubel DH, Wiesel TN. Early exploration of the visual cortex. Neuron 1998;20(3):401-12.

[98] Huttenlocher PR. Synaptic density in human frontal cortex developmental changes and effects of aging. Brain Res 1979; 163(2):195-205.

[99] Huttenlocher PR, de Courten C. The development of synapses in striate cortex of man. Hum Neurobiol 1987;6(1):1-9.

[100] Innocenti GM. Growth and reshaping of axons in the establishment of visual callosal connections. Science 1981;212:824-7.

[101] Insel TR. The development of brain and behavior. In: Bloom FE, Kupfer DJ, editors. Psychopharmacology: the fourth generation of progress. New York: Raven Press; 1995. p. 683-94.

[102] Jacobson M. Genesis of neuronal specificity. In: Rockstein M, editor. Development and aging in the nervous system. New York: Academic Press; 1973. p. 103

[103] Jacobson M. Developmental neurobiology. New York: Plenum Press; 1991.

[104] Jones JI, Gockerman A, Busby Jr. WH, Wright G, Clemmons DR. Insulin-like growth factor binding protein 1 stimulates cell migration and binds to the alpha 5 beta 1 integrin by means of its Arg-Gly-Asp sequence. Proc Natl Acad Sci USA 1993;90(22):10553-7.

[105] Jones LS, Gauger LL, Davis JN, Slotkin TA, Bartolome JV. Postnatal development of brain alpha 1-adrenergic receptors: in vitro autoradiography with $\left[{ }^{125} \mathrm{I}\right] \mathrm{HEAT}$ in normal rats and rats treated with alpha-difluoromethylornithine, a specific, irreversible inhibitor of ornithine decarboxylase. Neuroscience 1985;15(4):1195-202.

[106] Jung AB, Bennett Jr. JP. Development of striatal dopaminergic function. III: pre- and postnatal development of striatal and cortical mRNAs for the neurotrophin receptors trkBTK + and trkC and their regulation by synaptic dopamine. Brain Res Dev Brain Res 1996; 94(2):133-43.

[107] Kalsbeek A, Voorn P, Buijs RM, Pool CW, Uylings HB. Development of the dopaminergic innervation in the prefrontal cortex of the rat. J Comp Neurol 1988;269(1):58-72.

[108] Kato C, Petronis A, Okazaki Y, Tochigi M, Umekage T, Sasaki T. Molecular genetic studies of schizophrenia: challenges and insights. Neurosci Res 2002;43(4):295-304.

[109] Kaufman J, Charney D. Effects of early stress on brain structure and function: implications for understanding the relationship between child maltreatment and depression. Dev Psychopathol 2001;13(3): 451-71.

[110] Keller HH, Bartholini G, Pletscher A. Spontaneous and drug-induced changes of cerebral dopamine turnover during postnatal development of rats. Brain Res 1973;64:371-8.

[111] Keshavan MS, Diwadkar VA, DeBellis M, Dick E, Kotwal R, Rosenberg DR, Sweeney JA, Minshew N, Pettegrew JW. 
Development of the corpus callosum in childhood, adolescence and early adulthood. Life Sci 2002;70(16):1909-22.

[112] Keshaven M, Anderson S, Pettegrew JW. Is schizophrenia due to excessive synaptic pruning in the prefrontal cortex? The Feinberg hypothesis revisited. Journal of Psychiatric Research 1994;28:239.

[113] Keverne EB. Genomic imprinting in the brain. Curr Opin Neurobiol 1997;7(4):463-8.

[114] Keverne EB, Fundele R, Narasimha M, Barton SC, Surani MA. Genomic imprinting and the differential roles of parental genomes in brain development. Brain Res Dev Brain Res 1996;92(1):91-100.

[115] Kiss JZ, Troncoso E, Djebbara Z, Vutskits L, Muller D. The role of neural cell adhesion molecules in plasticity and repair. Brain Res Brain Res Rev 2001;36(2-3):175-84.

[116] Knoll B, Drescher U. Ephrin-As as receptors in topographic projections. Trends Neurosci 2002;25(3):145-9.

[117] Koob GF. Neurobiology of addiction. Toward the development of new therapies. Ann NY Acad Sci 2000;909:170-85.

[118] Kosofsky BE, Hyman SE. No time for complacency: the fetal brain on drugs. J Comp Neurol 2001;435(3):259-62.

[119] Kostrzewa RM, Saleh MI. Impaired ontogeny of striatal dopamine D1 and D2 binding sites after postnatal treatment of rats with SCH23390 and spiroperidol. Brain Res Dev Brain Res 1989;45(1): 95-101.

[120] Kuczenski R, Segal DS. Dynamic changes in sensitivity occur during the acute response to cocaine and methylphenidate. Psychopharmacol (Berl) 1999;147(1):96-103.

[121] Kuhn CM, Pauk J, Schanberg SM. Endocrine responses to motherinfant separation in developing rats. Dev Psychobiol 1990;23(5): $395-410$.

[122] Kukstas L, Domec C, Bascles L, Bonnet J, Verrier D, Israel J, Vincent J. Different expression of the two dopaminergic D2 receptors, D2415 and D2455, in two tpes of lactotroph each characterized by their response to dopamine, and modification of expression by sex steroids. Endocrinology 1991;129:1101-3.

[123] Kuppermann BD, Kasamatsu T. Enhanced binocular interaction in the visual cortex of normal kittens subjected to intracortical norepinephrine perfusion. Brain Res 1984;302(1):91-9.

[124] Landmesser LT. The generation of neuromuscular specificity. Ann Rev Neurosci 1980;3:279-302.

[125] Lankford KL, DeMello FG, Klein WL. D1-type dopamine receptors inhibit growth cone motility in cultured retina neurons: evidence that neurotransmitters act as morphogenic growth regulators in the developing central nervous system. Proc Natl Acad Sci USA 1988; 85(12):4567-71.

[126] Lauder JM, Krebs H. Serotonin as a differentiation signal in early neurogenesis. Dev Neurosci 1978;1(1):15-30.

[127] Laviola G, Dell'Omo G, Chiarotti F, Bignami G. d-amphetamine conditioned place preference in developing mice: relations with changes in activity and stereotypies. Behav Neurosci 1994;108(3): $514-24$.

[128] Laviola G, Wood RD, Kuhn C, Francis R, Spear LP. Cocaine sensitization in periadolescent and adult rats. J Pharmacol Exp Ther 1995;275(1):345-57.

[129] Leckman JF, Pauls DL, Cohen DJ. Tic disorders. In: Bloom FE, Kupfer DJ, editors. Psychopharmacology: the fourth generation of progress. New York: Raven Press; 1995. p. 1665-74.

[130] Leon M. The neurobiology of filial learning. Annu Rev Psychol 1992;43:377-98.

[131] Lerner P, Nose P, Gordon EK, Lovenberg W. Haloperidol: effect of long-term treatment on rat striatal dopamine synthesis and turnover. Science 1977;197(4299): 181-3.

[132] Levine SP, Towell BL, Suarez AM, Knieriem LK, Harris MM, George JN. Platelet activation and secretion associated with emotional stress. Circulation 1985;71(6):1129-34.

[133] Levitt P, Harvey JA, Friedman E, Simansky K, Murphy EH. New evidence for neurotransmitter influences on brain development. Trends Neurosci 1997;20(6):269-74.
[134] Lewine RJ. Gender and schizophrenia. In: Tsuang MT, Simpson JC, editors. Handbook of Schizophrenia: nosology, epidemiology and genetics. Amsterdam: Elsevier; 1988. p. 379.

[135] Lewis DA. Development of the prefrontal cortex during adolescence: insights into vulnerable neural circuits in schizophrenia. Neuropsychopharmacology 1997;16(6):385-98.

[136] Li E. Chromatin modification and epigenetic reprogramming in mammalian development. Nat Rev Genet 2002;3(9):662-73.

[137] Lidow MS. Cocaine abuse and corticogenesis. Trends Neurosci 1998;21(1):19-20.

[138] Lidow MS, Goldman-Rakic PS, Rakic P. Synchronized overproduction of neurotransmitter receptors in diverse regions of the primate cerebral cortex. Proc Natl Acad Sci 1991;88:10218.

[139] Lightman SL, Insel TR, Ingram CD. New genomic avenues in behavioural neuroendocrinology. Eur J Neurosci 2002;16(3): $369-72$.

[140] Lightman SL, Windle RJ, Julian MD, Harbuz MS, Shanks N, Wood SA, Kershaw YM, Ingram CD. Significance of pulsatility in the HPA axis. Novartis Found Symp 2000;227:244-57.

[141] Lillrank SM, Lipska BK, Weinberger DR. Neurodevelopmental animal models of schizophrenia. Clin Neurosci 1995;3(2): 98-104.

[142] Lipska BK, Jaskiw GE, Weinberger DR. Postpubertal emergence of hyperresponsiveness to stress and to amphetamine after neonatal excitotoxic hippocampal damage: a potential animal model of schizophrenia. Neuropsychopharmacology 1993;9(1): $67-75$.

[143] Lipska BK, Swerdlow NR, Geyer MA, Jaskiw GE, Braff DL, Weinberger DR. Neonatal excitotoxic hippocampal damage in rats causes post-pubertal changes in prepulse inhibition of startle and its disruption by apomorphine. Psychopharmacol (Berl) 1995;122(1): $35-43$.

[144] Lipska BK, Weinberger DR. Delayed effects of neonatal hippocampal damage on haloperidol-induced catalepsy and apomorphineinduced stereotypic behaviors in the rat. Brain Res Dev Brain Res 1993;75(2):213-22.

[145] Livingstone JD, Lerant A, Freeman ME. Ovarian steroids modulate responsiveness to dopamine and expression of G-proteins in lactotropes. Neuroendocrinology 1998;68(3):172-9.

[146] Lyss PJ, Andersen SL, LeBlanc CJ, Teicher MH. Degree of neuronal activation following FG-7142 changes across regions during development. Brain Res Dev Brain Res 1999;116(2):201-3.

[147] Mailleux P, Pelaprat D, Vanderhaeghen JJ. Transient neurotensin high-affinity binding sites in the human inferior olive during development. Brain Res 1990;508(2):345-8.

[148] Marenco S, Weinberger DR. The neurodevelopmental hypothesis of schizophrenia: following a trail of evidence from cradle to grave. Dev Psychopathol 2000;12(3):501-27.

[149] Mattson MP. Neurotransmitters in the regulation of neuronal cytoarchitecture. Brain Res 1988;472(2):179-212.

[150] Mazer C, Muneyyirci J, Taheny K, Raio N, Borella A, WhitakerAzmitia P. Serotonin depletion during synaptogenesis leads to decreased synaptic density and learning deficits in the adult rat: a possible model of neurodevelopmental disorders with cognitive deficits. Brain Res 1997;760(1-2):68-73.

[151] McEwen BS. Gonadal steroid influences on brain development and sexual differentiation. Int Rev Physiol 1983;27:99-145.

[152] McEwen BS. Non-genomic and genomic effects of steroids on neural activity. Trends Pharmacol Sci 1991;12(4):141-7.

[153] McGivern RF, Handa RJ. Prenatal exposure to drugs of abuse: methodological considerations and effects on sexual differentiation. NIDA Res Monogr 1996;164:78-124.

[154] McGuffin P, Riley B, Plomin R. Genomics and behavior. Toward behavioral genomics. Science 2001;291(5507):1232-49.

[155] Mermelstein PG, Becker JB, Surmeier DJ. Estradiol reduces calcium currents in rat neostriatal neurons via a membrane receptor. J Neurosci 1996;16(2):595-604 
[156] Mirnics K, Middleton FA, Lewis DA, Levitt P. The human genome: gene expression profiling and schizophrenia. Am J Psychiatry 2001; 158(9):1384.

[157] Morency M, Beninger R. Dopaminergic substrates of cocaineinduced place conditioning. Brain Res 1987;199:33-41.

[158] Mucha R, Kooy DVD, O'Shaughness M, Bucenieks P. Drug reinforcement studies by the use of place conditioning in rat. Brain Res 1982;243:91-105.

[159] Murrin LC, Zeng W. Postnatal ontogeny of dopamine D2 receptors in rat striatum. Biochem Pharmacol 1986;35(7):1159-62.

[160] Nestler EJ, Landsman D. Learning about addiction from the genome. Nature 2001;409(6822):834-5.

[161] Noisin EL, Thomas WE. Ontogeny of dopaminergic function in the rat midbrain tegmentum, corpus striatum and frontal cortex [published erratum appears in Brain Res 1989 May, 47(1) (1) 160]. Brain Res 1988;469(1-2):241-52.

[162] Novik KL, Nimmrich I, Genc B, Maier S, Piepenbrock C, Olek A, Beck S. Epigenomics: genome-wide study of methylation phenomena. Curr Issues Mol Biol 2002;4(4):111-28.

[163] Pardo JV, Creese I, Burt DR, Snyder SH. Ontogenesis of dopamine receptor binding in the corpus striatum of the rat. Brain Res 1977; 125(2):376-82.

[164] Peterson BS, Leckman JF, Scahill L, Naftolin F, Keefe D, Charest NJ, Cohen DJ. Steroid hormones and CNS sexual dimorphisms modulate symptom expression in Tourette's syndrome. Psychoneuroendocrinology 1992;17(6):553-63.

[165] Petronis A. The genes for major psychosis: aberrant sequence or regulation? Neuropsychopharmacology 2000;23(1):1-12.

[166] Pihoker C, Owens MJ, Kuhn CM, Schanberg SM, Nemeroff CB. Maternal separation in neonatal rats elicits activation of the hypothalamic-pituitary-adrenocortical axis: a putative role for corticotropin-releasing factor. Psychoneuroendocrinology 1993 ; 18(7):485-93

[167] Pitts DK, Freeman AS, Chiodo LA. Dopamine neuron ontogeny: electrophysiological studies. Synapse 1990;6(4):309-20.

[168] Plotsky PM, Thrivikraman KV, Meaney MJ. Central and feedback regulation of hypothalamic corticotropin-releasing factor secretion. Ciba Found Symp 1993;172:59-75.

[169] Preece MA. Puberty in children with intrauterine growth retardation Horm Res. 1997;48(1):30-2.

[170] Pujol J, Vendrell P, Junque C, Marti-Vilalta JL, Capdevila A. When does human brain development end? Evidence of corpus callosum growth up to adulthood. Ann Neurol 1993;34(1):71-5.

[171] Purves D. Body and brain: a trophic theory of neural connections. Cambridge, MA: Harvard University Press; 1988.

[172] Purves D, Lichtman JW. Elimination of synapses in the developing nervous system. Science 1980;210(4466):153-7.

[173] Rakic P. Development of visual centers in the primate brain depends on binocular competition before birth. Science 1981;214(4523): 928-31.

[174] Rakic P. Development of the primate cerebral cortex. In: Lewis M, editor. Child and adolescent psychiatry. Baltimore: Williams and Wilkins; 1991.

[175] Rakic P, Bourgeois JP, Eckenhoff MF, Zecevic N, Goldman-Rakic PS. Concurrent overproduction of synapses in diverse regions of the primate cerebral cortex. Science 1986;232(4747):232-5.

[176] Rao PA, Molinoff PB, Joyce JN. Ontogeny of dopamine D1 and D2 receptor subtypes in rat basal ganglia: a quantitative autoradiographic study. Brain Res Dev Brain Res 1991;60(2):161-77.

[177] Rapoport JL, Castellanos FX, Gogate N, Janson K, Kohler S, Nelson P. Imaging normal and abnormal brain development: new perspectives for child psychiatry. Aust NZ J Psychiatry 2001;35(3):272-81.

[178] Reik W, Dean W, Walter J. Epigenetic reprogramming in mammalian development. Science 2001;293(5532):1089-93.

[179] Rosenberg DR, Lewis DA. Postnatal maturation of the dopaminergic innervation of monkey prefrontal and motor cortices: a tyrosine hydroxylase immunohistochemical analysis. J Comp Neurol 1995; 358(3):383-400.

[180] Rosengarten H, Friedhoff AJ. Enduring changes in dopamine receptor cells of pups from drug administration to pregnant and nursing rats. Science 1979;203(4385):1133-5.

[181] Roth RH, Bacopoulos NG, Bustos G, Redmond Jr DE. Antipsychotic drugs: differential effects on dopamine neurons in basal ganglia and mesocortex following chronic administration in human and nonhuman primates. Adv Biochem Psychopharmacol 1980;24:513-20.

[182] Saenger P, Dimartino-Nardi J. Premature adrenarche. J Endocrinol Invest 2001;24(9):724-33.

[183] SAMHSA, Summary of findings from the 1998 national household survey on drug abuse. Rockville, MD: US Department of Health and Human Services; 1999. pp. 128.

[184] Sanchez MM, Ladd CO, Plotsky PM. Early adverse experience as a developmental risk factor for later psychopathology: evidence from rodent and primate models. Dev Psychopathol 2001;13(3):419-49.

[185] Sandyk R. Biological determinants and risk factors for tardive dyskinesia in schizophrenia. Int J Neurosci 1993;69(1-4):35-51.

[186] Sapolsky RM, Meaney MJ. Maturation of the adrenocortical stress response: neuroendocrine control mechanisms and the stress hyporesponsive period. Brain Res 1986;396(1):64-76.

[187] Scalzo FM, Spear LP. Chronic haloperidol during development attenuates dopamine autoreceptor function in striatal and mesolimbic brain regions of young and older adult rats. Psychopharmacology 1985;85(3):271-6

[188] Seeman M. The role of sex hormones in psychopathology: focus on schizophrenia. Primary Care 2002;29(1):171-82.

[189] Seeman MV, Lang M. The role of estrogens in schizophrenia gender differences. Schizophr Bull 1990;16(2):185-94.

[190] Seeman P, Bzowej NH, Guan HC, Bergeron C, Becker LE, Reynolds GP, Bird ED, Riederer P, Jellinger K, Watanabe S, et al. Human brain dopamine receptors in children and aging adults. Synapse 1987;1(5):399-404.

[191] Shemer AV, Azmitia EC, Whitaker-Azmitia PM. Dose-related effects of prenatal 5-methoxytryptamine (5-MT) on development of serotonin terminal density and behavior. Brain Res Dev Brain Res 1991;59(1):59-63.

[192] Sidman RL, Rakic P. Neuronal migration, with special reference to developing human brain: a review. Brain Res 1973;62(1):1-35.

[193] Slob AK, Huizer T, Van der Werff ten Bosch JJ. Ontogeny of sex differences in open-field ambulation in the rat. Physiol Behav 1986; 37(2):313-5.

[194] Snyder-Keller A, Keller Jr. RW. Stimulant-mediated c-fos induction in striatum as a function of age, sex, and prenatal cocaine exposure. Brain Res 1998;794(1):88-95.

[195] Spear L. The adolescent brain and age-related behavioral manifestations. Neurosci Bio-behav Rev 2000;24:417-63.

[196] Spear LP, Brake SC. Periadolescence: age-dependent behavior and psychopharmacological responsivity in rats. Dev Psychobiol 1983; 16(2):83-109.

[197] Spear LP, Shalaby IA, Brick J. Chronic administration of haloperidol during development: behavioral and psychopharmacological effects. Psychopharmacology 1980;70(1):47-58.

[198] Sretavan DW, Shatz CJ. Prenatal development of cat retinogeniculate axon arbors in the absence of binocular interactions. J Neurosci 1986;6(4):990-1003.

[199] Stevens R, Goldstein R. Effects of neonatal testosterone and estrogen on open-field behaviour in rats. Physiol Behav 1981;26(3):551-3.

[200] Stewart J, Cygan D. Ovarian hormones act early in development to feminize adult open-field behavior in the rat. Horm Behav 1980;14: 20-32.

[201] Stewart J, Skvarenina A, Pottier J. Effects of neonatal androgens on open-field behavior and maze learning in the prepubescent and adult rat. Physiol Behav 1975;14(3):291-5.

[202] Swarzenski BC, Tang L, Oh YJ, O’Malley KL, Todd RD. Morphogenic potentials of D2, D3, and D4 dopamine receptors 
revealed in transfected neuronal cell lines. Proc Natl Acad Sci USA 1994;91(2):649-53.

[203] Tang K, Low MJ, Grandy DK, Lovinger DM. Dopamine-dependent synaptic plasticity in striatum during in vivo development. Proc Natl Acad Sci USA 2001;98(3):1255-60.

[204] Tarter R, Vanyukov M, Giancola P, Dawes M, Blackson T, Mezzich A, Clark DB. Etiology of early age onset substance use disorder: a maturational perspective. Dev Psychopathol 1999;11(4):657-83.

[205] Tashima L, Nakata M, Anno K, Sugino N, Kato H. Prenatal influence of ischemia-hypoxia-induced intrauterine growth retardation on brain development and behavioral activity in rats. Biol Neonate 2001;80(1):81-7.

[206] Tatum A, Seevers M. Experimental cocaine addiction. J Pharmacol Exp Therapeut 1929;36:401-10.

[207] Teicher M, Dumont N, Andersen S. The developing prefrontal cortex: Is there a transient interneuron that stimulates catecholamine terminals? Synapse 1998;28:89-91.

[208] Teicher MH, Andersen SL, Glod CA, Navalta CP, Gelbard HA. Neuropsychiatric disorders of childhood and adolescence. The american psychiatric press textbook of neuropsychiatry, Washington, DC: American Psychiatric Press; 1997.

[209] Teicher MH, Andersen SL, Hostetter Jr JC. Evidence for dopamine receptor pruning between adolescence and adulthood in striatum but not nucleus accumbens. Brain Res Dev Brain Res 1995;89(2): $167-72$.

[210] Teicher MH, Barber NI, Gelbard HA, Gallitano AL, Campbell A, Marsh E, Baldessarini RJ. Developmental differences in acute nigrostriatal and mesocorticolimbic system response to haloperidol. Neuropsychopharmacology 1993;9(2):147-56.

[211] Teicher MH, Gallitano AL, Gelbard HA, Evans HK, Marsh ER, Booth RG, Baldessarini RJ. Dopamine D1 autoreceptor function: possible expression in developing rat prefrontal cortex and striatum. Brain Res Dev Brain Res 1991;63(1-2):229-35.

[212] Tepper JM, Trent F, Nakamura S. Postnatal development of the electrical activity of rat nigrostriatal dopaminergic neurons. Brain Res Dev Brain Res 1990;54(1):21-33.

[213] Timmusk T, Belluardo N, Persson H, Metsis M. Developmental regulation of brain-derived neurotrophic factor messenger RNAs transcribed from different promoters in the rat brain. Neuroscience 1994;60(2):287-91.

[214] Tischkau SA, Ramirez VD. A specific membrane binding protein for progesterone in rat brain: sex differences and induction by estrogen. Proc Natl Acad Sci USA 1993;90(4):1285-9.

[215] Tobet SA. Genes controlling hypothalamic development and sexual differentiation. Eur J Neurosci 2002;16(3):373-6.

[216] Todd RD. Neural development is regulated by classical neurotransmitters: dopamine D2 receptor stimulation enhances neurite outgrowth. Biol Psychiatry 1992;31(8):794-807.

[217] Tsuang M. Schizophrenia: genes and environment. Biol Psychiatry 2000;47(3):210-20.
[218] Upton AL, Salichon N, Lebrand C, Ravary A, Blakely R, Seif I, Gaspar P. Excess of serotonin (5-HT) alters the segregation of ispilateral and contralateral retinal projections in monoamine oxidase A knock-out mice: possible role of 5-HT uptake in retinal ganglion cells during development. J Neurosci 1999;19(16): $7007-24$.

[219] Velazquez-Moctezuma J, Diaz Ruiz O. Neonatal treatment with clomipramine increased immobility in the forced swim test: an attribute of animal models of depression. Pharmacol Biochem Behav 1992;42(4):737-9.

[220] Vermetten E, Bremner JD. Circuits and systems in stress. I. Preclinical studies. Depress Anxiety 2002;15(3):126-47.

[221] Vizuete ML, Venero JL, Traiffort E, Vargas C, Machado A, Cano J. Expression of 5-HT7 receptor mRNA in rat brain during postnatal development. Neurosci Lett 1997;227(1):53-6.

[222] Vogel G, Neill D, Hagler M, Kors D. A new animal model of endogenous depression: a summary of present findings. Neurosci Biobehav Rev 1990;14(1):85-91.

[223] Vogel G, Neill D, Kors D, Hagler M. REM sleep abnormalities in a new animal model of endogenous depression. Neurosci Biobehav Rev 1990;14(1):77-83.

[224] Walker EF. Developmentally moderated expressions of the neuropathology underlying schizophrenia. Schizophr Bull 1994;20(3): 453-80.

[225] Wang GH. Relation between spontaneous activity and estrous cycle in the white rat. Comp Psychol Monogr 1923;2:1-27.

[226] Weinberger DR. Implications of normal brain development for the pathogenesis of schizophrenia. Arch Gen Psychiatry 1987;44(7): $660-9$.

[227] Whitaker-Azmitia PM. Role of serotonin and other neurotransmitter receptors in brain development: basis for developmental pharmacology. Pharmacol Rev 1991;43(4):553-61.

[228] Whitaker-Azmitia PM, Azmitia EC. Autoregulation of fetal serotonergic neuronal development: role of high affinity serotonin receptors. Neurosci Lett 1986;67(3):307-12.

[229] Williams DI, Russell PA. Open-field behaviour in rats: effects of handling sex and repeated testing. Br J Psychol 1972;63(4): $593-6$.

[230] Witelson SF. Hand and sex differences in the isthmus and genu of the human corpus callosum. A postmortem morphological study. Brain 1989;112:799-835.

[231] Xiao L, Becker JB. Effects of estrogen agonists on amphetaminestimulated striatal dopamine release. Synapse 1998;29(4):379-91.

[232] Yokosuka M, Okamura H, Hayashi S. Transient expression of estrogen receptor-immunoreactivity (ER-IR) in the layer V of the developing rat cerebral cortex. Brain Res Dev Brain Res 1995;84(1): 99-108.

[233] Zheng D, Purves D. Effects of increased neural activity on brain growth. Proc Natl Acad Sci USA 1995;92(6):1802-6. 